\title{
Perspectives
}

\section{Diary of an Edu-Tourist in Costa Rica: An Autoethnographical Account of Learning Spanish}

\section{Heather Lotherington}

This article presents an autoethnographical account of my foray into Spanish immersion education in Costa Rica as a professor of multilingual education at a university in Canada. This language-learning journey was inspired by curiosity about the growing trend for Internet marketing of second-language learning as a form of tourism, which I label edu-tourism. I map the course of my edu-tourism experience, contemplating second-language learning in a local context, describing professionalism in private language teaching institutes, comparing pedagogical practice across various Spanish-as-a-second-language teachers, and documenting my experiential sociopragmatic acquisition of textbook Spanish.

Cet article présente un récit auto-ethnographique de mon expérience dans le domaine de l'immersion espagnole au Costa Rica en tant que professeure en éducation plurilingue dans une université au Canada. C'est ma curiosité face à la tendance de plus en plus répandue et que je nomme l'édutourisme-la promotion, par l'Internet, d'une forme de tourisme consistant en l'apprentissage d'une langue seconde - qui a inspiré mon séjour linguistique. Je décris les grandes lignes de mon expérience en édutourisme par une discussion de l'apprentissage d'une langue seconde dans un contexte local, une description du professionnalisme dans les instituts privés d'enseignement des langues, une comparaison de la pratique pédagogique de divers enseignants de l'espagnol langue seconde et un portrait de mon acquisition sociopragmatique de l'espagnol.

\section{Introduction}

I teach a seminar entitled Multilingual Education, open to graduate students of education and linguistics, which includes weekly topical online assignments. In one of these activities, participants are sent on a digital treasure hunt for instantiations of internationalization in language education. This assignment has yielded rich and varied findings in the chaos of Internet traffic, unveiling, for example, 
- information on revitalization efforts in indigenous language communities worldwide, e.g., Canadian First Nations languages (http://www.library.ubc.ca/xwi7xwa/lang.htm)

- online language and literacy learning/maintenance opportunities for diasporic small language communities, e.g., Tongan (http://loseli.tripod.com/tasks.html)

- online discourse and literacy opportunities for diasporic artificial language communities, e.g., the news in Esperanto (http://gxangalo.com/)

- online teaching of "dead" classical languages, e.g., Latin (http://www.wannalearn.com/Academic_Subjects/World_Languages/ Latin/)

- distance education language courses in real as well as artificial languages, including:

- guaranteed, instant foreign language learning using language teaching methods devised by self-identitified experts, for example, "Dr. Paul Pimsleur is now hailed as the household name in foreign language training" (http:/ /www.pimsleurdirect.com/s.nl/sc.15/.f)

- courses in pop-culture artificial languages, e.g., Klingon, created for the television series, Star Trek, and into which, according to the Wikipedia entry, Hamlet has been translated (http:/ / en.wikipedia.org/wiki/Klingon_language)

Another educational spin-off of globalization increasingly found in responses to this assignment is the proliferation of private language schools angling for international students seeking second-language immersion courses through online advertisements of what I describe as edu-tourism.

The Internet has revolutionized the basics of the economy, society, culture (Castells, 2000), and communication (Crystal, 2001; Lotherington, 2004a), affecting language and literacy practices and education enormously. The dynamics of globalized, interactive, technologically mediated communication have opened up dramatically new communicative spaces that have spawned new genres and new literacy conventions, practices, and expectations. The virtual world available on the Internet creates in essence a vast one-stop shop.

As Block and Cameron (2002) point out, "'communication skills' and the new literacies demanded by new technologies, as well as competence in one or more second / foreign languages, all represent valuable 'linguistic capital'" (p. 5). Paired with encroaching globalization that as Harris, Leung, and Rampton (2002) note, "is inextricably linked with the developments and demands of free-market capitalism" (p. 31), the marketing and practices of bilingualism and multilingualism have been profoundly affected. Heller (2002) describes the growing international trend to the commodification of bilingualism, focusing on Canada as an example. 
In their assignment responses, my students have located indications of the commercial success of marketing immersion foreign language courses online in countless possibilities for the study of second or foreign languages in syndicated as well as independent language schools in countries around the globe. In essence, the value of bilingualism acquired in an immersion context is being marketed in a tourism framework akin to the booming niche market of eco-tourism (see Figure 1).

I decided to do some personal online shopping for an immersion course to dust off my Spanish, studied over 30 years ago for my BA, and to experience second-language learning and teaching à la edu-tourism. My 15-year old daughter Maya accompanied me to learn basic Spanish never having studied the language. This article presents my perspectives on our journey through abridged and annotated diary entries threaded with practical and theoretical reflections.

\section{Methodology: Autoethnography}

I planned to document my edu-tourism journey to Costa Rica to improve my Spanish in the form of an autoethnography. An autoethnography is an emergent qualitative research methodology that captures and reflects on the

a) Learn Spanish language at immersion schools throughout Spain, Costa Rica, Ecuador, Mexico, the Caribbean and the rest of Latin America. Compare programs in 16 countries to find the best language course for you. Classes are available to all ages and all levels. Start to learn any Monday year round.

Each member of our staff has studied Spanish abroad. Further, we have repeatedly traveled to every Spanish-speaking nation in the world (20 different countries) to personally evaluate hundreds of immersion programs and host families. As a result of this emphasis, we have an enormous amount of first-hand knowledge about the culture, learning Spanish, language schools and immersion courses.

b) As you look around for the best place to learn Spanish or study Spanish Language abroad at a school or university, we are confident that you will find our site to be very useful and interesting. Take your time to discover all you need to know about what it takes to learn Spanish through our Spanish language immersion, study Spanish abroad and Spanish Language School semester programs. In addition to finding the best Latin American countries to study Spanish abroad either at a university or just to learn Spanish at a Spanish language school, you will also find in-depth information which will allow you to learn more about the cities and the countries where these Spanish Language Immersion Programs are located.

c) Spanish Language Immersion Program Overview

Spanish Language Course Topics Covered On This Page

- Why Immersion Programs Are So Effective

- Why Your Command of the Spanish Language Increases So Fast

- Why Homestays Are Such An Important Part of our Immersion Programs

Figure 1. Online promotions for Spanish immersion edu-tourism experiences. 
cultural through a first-person experiential perspective (Ellis \& Bochner, 1996; Reed-Danahay, 1997). The form challenges the borders of established qualitative research conduct and publication, as Holt (2003) carefully delineates, as it prominently forefronts the place of the researcher, who in any ethnographic research provides a crucial research lens, no matter how this is officially mapped onto the research process. I chose this method as the most valid way to capture my personal language-learning experience, which had as its aims:

- to experience and reflect on an Internet-advertised language immersion course located in another country, focusing on teaching practices and learning expectations, practical learning opportunities, and cultural-contextual facilitations and constraints;

- to improve my dormant Spanish in a total immersion context, reflecting on myself as a language learner.

My first step was to locate a private language school that best met my requirements, which included:

- a school that could be externally validated;

- language teachers with credentials;

- an advertised teaching approach that was theoretically and practically defensible;

- a school arranging local home stays as part of the experience;

- a macro-context of social, cultural, historical, and geographical interest;

- a national/local context of relative political stability.

I chose Costa Rica as a safe and interesting destination and consulted comparative guides of schools in the country to find a suitable institution, for example http://www.westnet.com/costarica/education.html\#language, http://www.languagecourse.net/schools—costa-rica.php3, Numerous clicks later, all educational and travel arrangements had been made.

\section{Immersion Education in Edu-Tourism Blurbs}

Language immersion as a teaching methodology was born in the bilingual and multilingual learning experiments of the 1950s and 1960s: the St. Lambert French immersion kindergarten (Québec, 1965), the Dade County twoway immersion program (Florida, 1963), and the first European School (Luxembourg, 1957; Lotherington, 2004b). Immersion education is fundamentally content-based school learning using the target language as the communicative medium. Language-learning results from meaningful exposure, interaction, and socialization in the classroom rather than from direct study of the grammar and vocabulary of the target language. Initially described as "immersion in a 'language bath" (Lambert \& Tucker, 1972, p. 225), immersion education as a language teaching methodology is now globally widespread (Johnson \& Swain, 1997). 
Edu-tourism promotional materials (see Figure 1) use the term immersion to describe the potential for authentic communication experiences in a cultural context rather than a content-based approach to language teaching. As such, immersion may be in a cultural rather than a language bath, and as I was to discover, this cultural bath is easily subverted economically.

\section{Week 1: July 2-5}

¡español con café! (Spanish with coffee!): reflections on input,

San José, el 2 de julio

We are on our way to Costa Rica for three and a half weeks of intensive immersion Spanish study at a private language school with campuses studded around the country. I have chosen to preface our intensive study with an orientation program offered by another organization in the capital San José. All arrangements have been made on the Internet.

For the first four days, we are guests at a United States-run school in San José where we are involved in what is advertised as an orientation to Costa Rica for Spanish-language students, but is in reality thinly veiled tourism packaged as language and culture education, and in this case very thin on the professional understanding and experience of both local language and culture. I must admit my surprise at the ambience of the student house, which is very American; aside from the Nicaraguan cook, the resident guides are young Americans who function mostly in English. Maya and I are clearly more experienced language-learners than most of our fellow students or hosts, having lived and worked in various international contexts and coming from officially bilingual Canada and manifestly multilingual Toronto. Indeed my rusty academic Spanish, learned 30 years ago in university, is arguably better than that of our young American guides.

An interesting lesson opportunity happens at the Peruvian restaurant tonight where our large and eclectic student group is taken for our first dinner. The place mat is an illustrated poem entitled Alturas del Macchu Pichu (Heights of Macchu Pichu) by the 20th-century Chilean poet Pablo Neruda. I ask the waiter, an expatriate Peruvian, to read it to me. He obliges hospitably, carefully reading the poem aloud and patiently explaining it as best he can in Spanish, supplementing his explanations with drawings on the place mat. I practice the poem to myself in the interludes when he has to dash off to serve a customer. He returns until he has finished his unhurried, carefully annotated reading. I make a mental note to buy a book of Pablo Neruda's poetry. As it turns out, this chance restaurant reading will be the only guided reading of canonical Latin American literature I am to have on this trip.

San José, el 4 de julio

In the climate of post 9-11 politics, not being US citizens means that Maya and I are barred from the US embassy celebrations that our guides have planned for resident students today. I marvel at how the July 4th American 
celebration is construed as an orientation to Costa Rica. When the school administrators realize that my daughter and I are Canadian, they embarrassedly send us on an all-expenses-paid tour of a large coffee plantation, where we happily encounter plenty of Spanish and excellent coffee. The tour is led by a small team of fluently bilingual Costa Rican actors in juxtaposed rather than translated English and Spanish, loaded with historical and social information and heavy on humor. We need both languages to follow everything, but the language encounter is nonthreatening and visually engaging; there is no pressure on us as audience to perform in this language of fragile comprehension. Our guides are fluid cultural mediators, bringing together and keeping interested and sufficiently in the know tourists from North, Central, and South America.

Their cross-cultural mediation makes me think about language teaching in terms of cultural and linguistic bridging. Our bilingual orientation to the tour requires us to listen carefully to hear what is going on, but it gives us the chance to review hypotheses about meaning when the guides switch to English and to predict when they switch back to Spanish. They provide us with ideal content-based learning in their bilingual introduction to the history and production of coffee. We are entertained and informed and leave the plantation knowledgeable, thoroughly caffeinated, and thinking in Spanish. The de facto need for bilingual navigation, given the range of paying tourists, creates a variant on those boutique '80s conversational language courses such as French with wine or Russian with vodka: ¡español con café!

ipura vida! (pure life!): "lessons" in naturalistic learning

San José, el 5 de julio

I am curiously given an introduction to informal language-learning à la Ricardo, our Filipino-American guide whose language proficiency is dicey and liberally sprinkled with the expression ipura vida! literally "pure life," an idiomatic Costa Rican exclamation of general well-being. (All names except mine and my daugher's are pseudonyms.) He also knows the names of the dances and the drinks, but the finer points of actually talking to people he seems not yet to have got down. It is interesting, if rather galling, to listen to him talk about learning Spanish from his experiential perspective of picking up Spanish on the streets of San José. He clearly espouses what Doughty (2004) terms "the noninterventionist argument" (p. 181) for second-language acquisition (SLA): SLA as implicit acquisition, controversially hypothesized as a binary to instructed learning by Krashen (1981, 1982, 1985). As such, Ricardo's experience of unstructured survival-language acquisition is indeed a curious introduction to our incipient formal language study.

His advice to beginning language students on how to learn a language is: talk to locals, read children's books, and read the subtitles on movies and TV shows. This reminds me of how easily language teaching is deprofessional- 
ized and SLA conveniently relegated to human experience. Ricardo's Spanish is a giveaway. He is anything but fluent apart from the nightclub scene. I wonder what children's book he read to find the name of the Colombian firewater he dares us all to try before spinning onto the dance floor.

I am discouraged to find so many of my fellow students linguistically unadventurous, afraid to try, and thinking always that English will do. The twenty-somethings are into drinking, dancing, and hot times with a Spanish morpheme or word occasionally interjected into otherwise English sentences, which seems to suffice to them: a sort of sympathetic Spanish-flavored English. A few students are making an effort to try a little Spanish, but it is enormously self-conscious. Bilingualism requires decentering, or maybe recentering within the self: culturally refocusing to include another set of values inherent in the language and culture of the target speech community in what Kinginger (2004) describes as "the process of negotiating and (re)constructing a coherent and satisfying identity" (p. 220). This is a leap for those not accustomed to multiculturalism in any linguistically democratic form.

Ser estudiante otra vez (On being a student again): appreciating the perspective of the language learner

Week 2: July 6-12

San Joaquin de Flores, el 8 de julio

At the end of our orientation to Costa Rica, suspiciously geared to the bar and cheap eats scenes of San José, participating students leave for various language courses around the country. We are relieved to depart for our first Tico (Costa Rican) family, leaving ambient American English for Costa Rican Spanish, the reason we are here.

We have been in our respective Spanish classes for two days now and are becoming pros at getting around San Joaquin de Flores, which is the little town or pueblo where the main campus of this school is located. Our hosts are gracious and hospitable middle-class Costa Ricans, very encouraging of my halting Spanish and tolerant of my daughter's beginner's reluctance to speak Spanish.

Maya and I have been placed in classes at opposite ends of the academic spectrum based on our placement tests. Maya, who has never studied Spanish before, is placed in the first level in a class of four with two university students and an elementary schoolteacher; I am placed in the most advanced level for our intake in a class of two with a 16-year-old boy from Denver who is here with his father, a specialist in emergency medicine wanting a better grip on Spanish for his work. Alan has studied Spanish for several years in high school and is grammatically proficient. Our teacher Linda is Colombiana, but has lived in Costa Rica for 19 years. I am clearly 
behind Alan in grammar, but more adventurous in speech, which seems to be coming back to me quickly in a Spanish-speaking environment.

Classes are from 8:00 a.m. to 12:00 daily with a break for café, té y refrescos (coffee, tea, and soft drinks). The institute's teaching approach is advertised in the school's English-language promotional literature as follows.

[Our] methodology emphasizes practice in conversation combined with grammatical exercises. The text books used in class (a vocabulary book and a grammar book for each level: beginner, intermediate, advanced) were developed by [our school's] director. Additional instructional materials include: videos, audio cassettes, reading materials and grammatical exercises.

Alan's and my customized program of studies follows an in-house exercise book (intermediate level), supplemented by a grammar book outlining verb tenses and a book of conversational vocabulary. I leaf through the libro de tareas (workbook). On page 1, where we start our course, is a basic fill-inthe-blanks greeting; on page 2 a review of regular verbs in the present and past tenses. By page 3, we have jumped into a local story about gardening.

By 11:30 por la mañana (a.m.) after three and a half hours of intensive study, my head turns to wood. I am so mentally exhausted I don't think I could conjugate a regular verb in the present tense. At the end of the class I encounter a new word that will be reinforced daily: tarea: homework. Interesting switch! Alan groans; he knows the word well.

I see that it is necessary to let the brain rest. The continual barrage of second-language input becomes counterproductive at some point. In my mind I can see the face of a little South American boy who joined the grade 4 ESL class I observed during a year-long ethnographic study in an elementary school in Toronto (Lotherington, 2006). In the beginning Carlos would look exhausted every day and would lay his head on the table rather than work. I thought he wasn't getting enough sleep at home. Now I realize that he was probably feeling much as I do now: mentally exhausted by the effort of continually trying to understand the world through the filter of another language. As my sabbatical study year at Main Street School progressed, I marveled at the charming and energetic little soccer player and computer buff who emerged from that sleepy little boy. Now I am beginning to appreciate the brain fry he must have experienced, arriving on the doorstep of Main Street School without any prior English.

Linda, my teacher, keeps telling me to spend $100 \%$ of the time on the language-learning task: to speak Spanish all the time. This unenlightened advice supports subtractive rather than additive language-learning (Lambert, 1974) and seems terribly hypocritical given that the school caters largely to Americans, and most tourist operators feeding on the school population 
simply use English. In fact one tour we take turns out to be guided by a monolingual English-speaker who has lived in Costa Rica for decades.

Linda's admonition blindly ignores my rapport with my daughter and Alan's with his father, both in English. We are adding Spanish to our respective linguistic repertoires, not exchanging competence in English for Spanish. Moreover, in a language school catering largely to edu-touriststeachers on vacation and university students looking to beef up their Spanish and catch some sun-no one is learning Spanish for life-sustaining purposes. I think about the ESL and FSL teachers in Canada who instruct newcomersstudents and families who are vulnerable due to their need for English (and/or French) to survive-to speak only English or French at home in a similar vein of enthusiastic if theoretically ignorant advice. Where do teachers come by such dangerous and inhumane notions?

San Joaquin de Flores, el 10 de julio

Our Tico family is interesting. Our host Alberto, a man in his mid-40s, works for a large international computer firm. Although it is evident that he speaks English, he does not attempt to use it, and I am grateful. His wife Maria Elena has a local accent that is much harder to penetrate. Alberto is well educated and likes to discuss social issues; his social conscience is in concert with the progressive social politics of the country, which has no army, supports public health and education, and is intimately connected with eco-tourism, although I note this public ecological conscience is not especially evident in the quotidian street life of our pueblo, which has broken sidewalks, abundant litter, and pedestrian-unfriendly traffic. Alberto was born on a large USowned banana plantation near Panama and is not afraid to discuss bananarepublic social politics, which I find fascinating. Our lengthy conversations after dinner and to a lesser extent at breakfast are intense learning opportunities for me. Alberto likes to talk, is intelligent, well educated, and well traveled. He is a patient listener and helps me along where I have said something obviously wrong. He is linguistically highly comprehensible, a trait less easy to ascribe to Maria Elena, whose energetic conversations about fashion trends leave me squirming, trying to find a way into her fast, colloquial Spanish. Is this because she is a less clear speaker than he, or is it because I am more interested and knowledgeable about social policy than I am about fashion? What is it that makes me work so much harder to understand her?

I do learn a local usage from Maria Elena that I reflect on: to gracias (thank you: literally a plural benediction of "grace"), she says con gusto (with pleasure), which is a way of expressing "you're welcome" that I have never before encountered. It makes perfect sense. Gusto, from the irregular verb gustar, denotes taste or pleasure. We have borrowed gusto into English, but use it to signify enthusiastic enjoyment. As a university student I learned con 
mucho gusto (with much pleasure) as a stock phrase-the textbook response to a personal introduction-but I had never thought to examine the components of the phrase. ¡Gracias, Maria Elena!

Maya says nothing at the dinner table, clearly experiencing her personal silent period in acquiring Spanish. Perhaps this would be better labeled the silenced period. Granger's (2004) psychoanalytical reading of the silent period, typically glossed as a period of listening to and absorbing language in the SLA literature, explores the anxieties inherent in reshaping a bilingual or multilingual identity. Although my daughter is a gregarious, experienced second-language learner, her face is contemplative of the self within this new cultural milieu as much as it is acquisitive of sufficient vocabulary to mobilize a basic conversation.

San Joaquin de Flores, el 11 de julio

The week passes quickly after we settle into the routine of morning Spanish classes, various afternoon tours, cooking and dancing lessons, as well as forays into the sleepy little town of San Joaquin de Flores, and the continual tarea (homework). Class is becoming less taxing as Alan and I move onto vocabulario (vocabulary) and demonstrative pronouns in our book, after tackling devilish verb tenses used in argentino (Argentinian), and costarricense (Costa Rican) legends about toads and crows. Somehow we got stuck reading the myth of Narcissus in Spanish. The organization of course materials is eclectic to say the least and certainly erratic in terms of exercise difficulty. Our course is communicative by dint of the small class size, but not in the nature of the activities, which center on traditional grammar-focused exercises, reading passages, and vocabulary.

Interestingly, Maya's elementary group is progressing at unequal rates. Her fellow students include a US medical student who speaks Russian at home and knows other languages and two other young monolingual Americans. Maya, who studied French in immersion programs in Canada and Australia and was spoken to in her infancy by her paternal grandmother in Polish and later in her childhood by our live-in housekeeper in Fijian, is like her multilingual Russian-American colleague, learning quickly in keeping with research evidence indicating that "bilingualism favours the acquisition of third languages" (Cenoz \& Genessee, 1998, p. 20.) Her two monolingual colleagues are noticeably slower in grasping elementary Spanish. 
Week 3: 14-19 July

Hay solamente que memorizar un poco (You only have to memorize a little): enduring the expectations of the teacher

Guanacaste, el 14 de julio

Our next campus is at a west-coast beach resort that requires a long bus trip, graduating us into tropical flora and fauna. El fin de semana (On the weekend) we took a jungle cruise where we saw the Costa Rica of advertisements complete with iguanas, caymans, howler monkeys, a sloth, a beautiful poisonous frog, and numerous birds. Although the boat driver was a young man who spoke only Spanish, our guide spoke to us in English. I am distressed at how easy it is to encounter English here. But as the tourist guide explained to me (in English), most foreigners in Costa Rica are Nicaraguans with little education and less money. The "Americans" are a welcome respite as they have money and spend it. So there it is: money talks and decides the language spoken. What does this say about the true language of communication in our learn-to-speak-Spanish-in-Costa-Rica adventure?

Guanacaste, el 15 de julio

It is very hot and sticky at our beach campus, and there is plenty of ambient wildlife. We are awoken in the middle of the night by howler monkeys that inhabit the trees across the street from our bed and breakfast. At 3:00 a.m. I am convinced they are werewolves. The mosquitoes are also talented, seemingly able to bite through insecticide. On the positive side, I notice that there are more butterflies here than I have ever seen anywhere in my life, and I spend the time waiting for the bus to school gazing at colorful fluttering insects.

The dueños (proprietors) of our bed and breakfast are native speakers of Italian; thus we need to use Spanish interculturally (Clyne, 1994). Now I know what it feels like to use a language as a lingua franca: Spanish is neither their native language nor ours, but it works as a functional link. Good thing: we have no hot water, although it takes me two days to realize this in the searing tropical heat.

Transport to school from our bed and breakfast is limited, but the bus driver can be counted on to speak Spanish. In fact for reliable Spanish conversation outside of family homes, I am learning to head systematically for the less educated workers: the drivers on tours, the waiters in local restaurants, the staff at the Internet café.

At school Alan and I are placed in a beautiful air-conditioned lounge perched on the second floor of the school with a view of the surrounding jungle. My daughter's classroom, on the other hand, is al fresco beside the swimming pool complete with two resident iguanas, a community of hungry and vicious red ants, and a giant crab. They move after the students protest the painful red ant bites, but the ants are not the only agony. Maya continues 
with a slow monolingual student from her first week in San Joaquin de Flores, her fast multilingual colleague having elected to stay at the main campus. As the week progresses, the slow student drops out for the lure of the beach, Spanish having become too tedious an enterprise; so Maya has private tuition, which moves much more quickly into a real communicative learning endeavor. However, it is clear that the culture of this campus has more to do with la playa (the beach) than with really studying Spanish, and when students are called on to use the second language, many of those accustomed to the power of ubiquitous English bail. Then again, I wonder about the frustration levels of students who find that they are not progressing quickly in a class where others are, considering that "several research studies [have] indicated that teachers treat students they consider good learners differently from those students they consider poor learners" (Naiman, Frölich, Stern, \& Todesco, 1996, pp. 180-181).

The teacher assigned to Alan and me at this campus, Juanita, is a young woman native to Guanacaste, the province in which this beach campus is located. Juanita is diligent and sincere, but not very experienced, and it is evident that she is not herself bilingual. This is a valuable learning opportunity: how many Canadian ESL teachers speak the language(s) of their students? Juanita's monolingualism is not a problem for Alan or me, but I note that the other teachers I am assigned throughout this course do know English. I marvel at the number of language teachers recruited in such a small provincial community given the tiny class sizes of the numerous private language schools in the country. The institute advertises its teachers as "experienced professors specifically trained in [our] methodology." It is clear that Juanita has training in teaching Spanish; however, she is manifestly nervous with us. Although she varies our lessons and assignments, the learning strategies anticipated in grammar instruction are clearly spelled out: Hay solamente que memorizar un poco (You only have to memorize a little).

Un banana split con dos cuchillos, por favor (A banana split with two knives, please): reflections on sociopragmatic learning

Guanacaste, el 16 de julio

On this hot day, stuck in town, Maya and I decide to indulge in a banana split, which shows up on the menu as an obvious English borrowing. Having some shred of sanity, we decide to split our banana split: one banana split with two spoons. But as I begin to give our order to the waiter: Señor, por favor, un banana split con dos ... I suddenly hesitate: is it cuchillos (knives) or cucharas (spoons)? Without missing a beat the waiter fills in "cucharas, sí Señora." The sudden lack of security in locating the correct lexical item sharpens this moment, lodging the word cuchara solidly in the food and dining section of my memory, never to be confused again. This involvement 
of memory is a far cry from Juanita's admonitions to memorize decontextualized lists of irregular verbs.

Guanacaste, el 17 de julio

An interesting grammatical idiosyncrasy of Costa Rican Spanish has emerged in Juanita's class. I have noticed that conjugations are typically presented in a simplified table of four basic forms excluding the informal you both in the singular and the plural forms. Spanish has informal and formal second-person forms in its pronominal set that vary in usage and form across varieties: in castellano (Castillian Spanish), the plural form of the second person vosotros/as is used. However, this form is not common outside España. I now discover that in Costa Rica the singular form of the second person $t u$ is also not typically used, which is anomalous in the Spanish-speaking world. Juanita states that neither tú nor vos is used in Costa Rica. In Argentina vos is the informal pronominal form preferred to tú. In Guatemala both informal forms $t u$ and vos are used in complementary distribution, each with a formality range and separate declension. The grammatical resource book the school recommended we buy before coming to Costa Rica, 501 Spanish verbs (Kendris, 1996), states unambiguously that there are two forms of the second person pronoun: informal and formal in both the singular and plural. No mention is made of vos. There is clearly a considerable gap between theory and practice in Spanish grammar.

When I ask Juanita about the missing informal form of you, she explains that $t u$ is understood by the Costa Rican population as belittling. What I have always understood as a horizontal social space delineating familiarity and intimacy she describes as a vertical social distancing, delineating condescension. I am mortified: I do not know how to amend my usage. Sorting out when to use forms that do not exist in one's first language is always a trial as there is no cognitive, social, or cultural hook on which to hang the new forms even if they are to be adjusted sociopragmatically. What do I do now?

Usted (formal you) seems to me so socially alienating. How can I call Alan usted? He is my young classmate with whom I have developed a friendly rapport through mildly competitive assignments, collegial jokes about too much homework, and a teasing prerogative that comes from being old enough to be his mother, not to mention having a daughter his age. He is a great kid: a definite tú. How on earth could I address him as usted?

Guanacaste, el 18 de julio

Our young teacher promises to treat us to a movie on our last morning. It is Shrek, which I have seen, mercifully, because I understand little of in it in Spanish. This is because my middle-aged ears cannot cope with the auditory conditions: loud ambient air-conditioning, lousy videotaped sound, and dubbing, which means that the lips of the characters don't move in sync with the spoken word, reducing opportunities for predictive listening. The other 
students in the conjoined classes watching the movie are young, sitting closer to the screen, and better equipped to hear across the confounding noise. I am reminded of ESL listening tests where we intentionally inserted auditory interference to simulate conditions of reality. I now see how ageist this practice is. I don't want to listen to this movie; it is too demanding a physical effort just to hear it.

I have learned a lot of grammar in Juanita's class. However, attending to those rules has slowed down my speech and encumbered fluency as projected in Krashen's (1985) Monitor Model decades ago: “While focusing on form may result in somewhat more grammatical accuracy, it does take more time" (p. 2). Staying at a bed and breakfast has reduced my opportunities for passive domestic exposure to Spanish, particularly as the dueños speak Italian with each other. I am looking forward to moving back into a Tico home.

Week 4: 20-26 July

Toucans, you know, like on Froot Loops: language in cultural context

Monteverde, el 21 de julio

We arrived in the beautiful, if chilly and wet, Monteverde rain forest reserve last evening after a treacherous and slow climb through dusty mountain roads full of more bumps than road. Unfortunately, we had a minor bus accident en route, which is apparently a rather common occurrence in this country. On the way we visited an active volcano, which we saw under dense cloud cover, and hiked into the rain forest with a knowledgeable local guide who claimed to have learned to speak English from watching television and clearly had no interest in speaking Spanish to anyone. Our entire tour group innocently trod beside a deadly and impatient-looking fer de lance viper, which seemed rather comical after the fact given that the guide hadn't even spotted it; a member of our group did. The voyage held many physical wonders: spider monkeys, toucans, hot springs, cold waterfalls. Our guide used heavily media-inspired English in his commentary, sprinkling his observations with US pop culture references, describing toucans as "you know, like on Froot Loops."

We are staying with Mónica and Francisco, a young working-class couple who are very accommodating; they board students every week as a source of permanent income. As such, they are professionals and know how to make foreigners feel at home. They have a gorgeous, cheeky little 2-year old son Josito, who has about as much Spanish as Maya and likes to invade my room regularly on his vroom-vroom tricycle. He has an active vocabulary of about 10 words including prominently aquí (here) and no, typically produced at high volume.

Ricardo's spurious how-to-learn-Spanish-on-the-street lessons are coming back to me as Josito and I get into reading children's picture books 
together. This seems to be a good compromise as he is inordinately interested in my workbooks, though I can't fathom why: they seem boring to me. He isn't too fussy about my pronunciation as long as he can make all the car noises in each story.

Talking with Josito is low-stress Spanish practice. But I do have a dilemma. Is Josito tú? How do I call a 2-year-old usted? I listen as his mother clearly addresses her toddler as usted. This not only goes against everything I have learned over 30 years, but also the usage seems so localized that I wonder how to deal with it. What is the place of immediate social context in language-learning? As Mitchell and Myles (1998) state, "The learning process itself may be viewed as essentially social, and inextricably entangled in L2 use and L2 interaction" (p. 20). I use usted.

Monteverde, el 22 de julio

Alan has gone back to the US, so I am now in private tuition with my teacher Margarita, originally from coastal Guanacaste, but resident in the cool mountainous forest reserve of Monteverde for many years. The nature of our classroom talk is different without the companionship of a class partner, but Margarita is as dedicated to conversation as Juanita was to grammar, and we have long and topically unlimited discussions, which allow me to attempt to put into practice some of my recently memorized verb constructions. Being of a similar age, we discuss families, teenagers, marriage, and machismo. Our discussions are therapeutic as well as pragmatic, and I welcome her suggestions for motivating teenagers to clean up.

Oddly, I find myself looking for a more engaged focus on form. My conversations highlight my inarticulateness; at the same time, I can see that I have learned a lot of Spanish. Margarita is reassuring; her verdict is: "Lo que necessita usted es confianza" (what you need is confidence), but I find our grammar lessons frustratingly isolated from our discussions, tacked onto the end of each lesson rather than threaded into the day's conversation. Although Doughty (2004) notes "the case for explicit instruction has been overstated" (p. 199), she also concedes that "when the outcome of very short-term, explicitly focused instruction is measured on language manipulation tasks, it has proven effective." (p. 198). I need some grammatical spot-welding.

Extracurricular tours are also problematic: how do you acquire confidence speaking Spanish when most of the accoutrements of the edutourism experience are in English?

Monteverde, el 23 de julio

At the Monteverde campus ambient Spanish is far more available than it was at the beach-resort Guanacaste campus. One of our administrators is French, making Spanish the intercultural link for most students. A brilliant opportunity for using Spanish in context happens in an extracurricular cooking 
lesson this afternoon. The cook, who is local, provides us with a recipe explaining how to make sopa de verduras con carne molida (vegetable soup with ground beef) and gives us various tasks: peeling, chopping, frying, stirring. This is not vegetable soup as I know it: these are local tropical vegetables, and we assistant cooks discuss what the vegetables might be called in English. A communal meal follows in which students, administrators, teachers, and the cook sit down together and enjoy our soup. ¡Que aproveche! (Enjoy your meal!). What a marvelous collaborative learning project.

My forays into the town of Monteverde have developed a shopping focus. First I had to look for crayons and a coloring book for my amiguito (little friend) Josito, to wean him from playing with my mechanical pencil so that I could complete my daily tarea.

Then I went looking for herbal tea after Mónica, my 22-year-old Tica mamá, fixed a bout of headache and nausea with a local herbal tea. Labels do not code-switch as sales people are apt to. I needed to buy Coli-te: té para los colicos (Coli-tea: tea for stomach upset) in the supermarket: a wonderful practical literacy lesson. The experience yielded a goldmine of local herbal tea remedies.

More urgently, Maya has developed an allergic reaction, and I need to find some decongestant eye drops. I carefully prepare in advance how to describe her medical condition in Spanish, then consult the local pharmacist, awkwardly describing all her symptoms and asking for appropriate medication. The pharmacist nods gravely, holds up a finger in aha! mode, and returns with antihistamine eye drops on which she has carefully typed directions for use - in English.

Monteverde, el 24 de julio

Mónica's twin sister joins us for dinner tonight, during which she gives a classic mini-language lesson to 2-year-old Josito. We are eating chicken: pollo. She carefully repeats this to Josito, forking her own piece of chicken demonstratively. He continues to eat with concentrated vigor, paying no attention to this intrusion in his dinner. She insists, "pollo, Josito, pollo." He looks and chews. The lesson continues intermittently for the length of Josito's dinner, and he comes out with a few vague attempts but does not say pollo. He dashes off to play after eating, and his aunt casually shrugs off her unsuccessful attempt at lexical instruction.

Monteverde, el 25 de julio

At breakfast, Josito comes bombing into the dining room at high speed while Maya and I are eating, grabs his spoon with a concentrated fist, and digs into his cornflakes with gusto. Suddenly he looks at me, spoon in mid-air, and gleefully announces: pollo!

Josito's misadventures with the word pollo stir memories of the many times I have obviously said the wrong thing that was socially amusing in the 
Costa Rican context. My communicative boo-boos have evoked consistently kind reactions, though always a gentle correction. Sometimes I have suddenly realized that what I am saying couldn't be right and have self-corrected. "Excuse me while I clean my lentils (lentejas)—oops, glasses (lentes)" was a hysterical near miss even to me. The embarrassment of coming out with such nonsense, including the episode where I nearly ordered a banana split with dos cuchillos (two knives) instead of dos cucharas (two spoons), seems to turbo-charge my memory. Social embarrassment, in other words, motivates learning.

But it is clear that 2-year-olds have not yet developed a crippling sense of social embarrassment, as we discovered when Josito was bouncing around on the sofa and had a little accident that his mamá made rather memorable for him. Perhaps when one is still working on bladder control, the words for foods that will be served no matter whether you can label them or not are not so crucial. Pollo indeed.

It turns out that tomorrow is a national holiday, so this is the end of our course of studies. I have enjoyed the language-learning experience immensely and have clearly benefited from both classroom instruction and contextual opportunities to use Spanish as a medium despite the inevitable frustrations and hurdles.

Josito gives us both a beso (kiss) as we leave his home in this stunningly beautiful mountainous rain forest for the warmer climate of San Joaquin de Flores before flying back to Canada.

\section{Conclusion: Qué apprendí yo? (What did I learn?)}

My aims for this language-learning expedition, sparked by indications that second-language learning was becoming internationally commodified as a branch of tourism in ways inviting educational exploration, were to experience and reflect on a second-language course in a Spanish-speaking country found via the Internet, and to improve my Spanish in a total-immersion context. In the process, as an individual learner within the machinery of two (linked) globally marketed, privately run foreign-language institutions, I encountered a number of curious paradoxes that underscore the importance of caveat emptor in the online educational marketplace.

Globalization and Language-learning:

On Edu-Tourism in Costa Rica

Our edu-tourism experience, found through the medium of the Internet, was fun, enlightening, and a little off the beaten tourist track: bona fide, if optional, enrichment-oriented education. Our experience included two organizations: a well-organized, recommendable Costa Rican-owned and managed private language school, where methodical in-house coursebooks were taught by trained and relatively experienced native Spanish-speaking teach- 
ers, though specific professional qualifications were not advertised; and a much less satisfactory US-owned and run "institute" handling cultural orientation: really a front for estadounidense (US) tourists pretending to have a learning experience, with nary a native speaker in sight apart from the itinerant Nicaraguan cook.

Prospective students need to engage the search potential of the Internet to locate independent critical commentary on private schools before enrolling. Google gives hundreds of thousands of responses to "Spanish courses in Costa Rica"; finding triangulating commentary in more scholarly portals is highly recommended.

Immersion in the classical methodological sense, this classroom learning experience both was and was not: a curious paradox. The language-teaching agenda focused clearly on the language as an object. I plowed through lists of vocabulary and memorized tenses and irregularities. This is not contentbased leaning, which defines immersion approaches. But the very teachers who forced such strategies on me also used Spanish as a medium of communication, and it was never overwritten by English in classroom encounters. In that sense, the experience was language immersion.

My experience of the relative valuing of languages used in Costa Rica on this trip was troubling. English was clearly the language of motivation and of economic action in the tourist sphere in Costa Rica; Spanish was the commodity being sold. Where money was an issue, Costa Ricans bent over backwards to use English: to get us enrolled in their educational programs, transported to their schools, and signed up for tours, and to check that we were happy with what we saw and learned. I was dismayed that English was used so overwhelmingly on tours directly associated with language schools. Ominously, the most authentically bilingual touring experience Maya and I had was the consolation coffee plantation tour hastily arranged when it was realized that we were ineligible to attend the US Embassy's 4th of July celebrations. Clearly English has emerged as a de facto second language in Costa Rica.

On Second-Language Learning Theory in Practice.

I was conscious of the place of comprehensible input, comprehensible output, and form-focused instruction in my varied language-learning opportunities. The physical blockage of comprehensible input was surprising to me: audible language is implicit in aural comprehensibility. The concurrent air-conditioning noise in the Shrek video screening provided too much interference for me to understand a dubbed movie; the experience was simply defeating. Would this have prevented me from following the movie in English? I don't know. In dubbed Spanish, questions of cognition lay beyond; physical limitations presided. 
The comprehensibility of individual speakers too was variable, and speed and clarity mattered; this was not a question of authenticity, but of navigability. I experienced problems understanding Maria Elena, our Tica mamá in San Joaquin de Flores, who spoke quickly and colloquially. In attempted conversations with her, I sank to elemental processing of individual words, which was frustrating and depressing. Interference in aural comprehensibility short-circuits the listening process just as difficult vocabulary drives reading down to bottom-up processing (Hudson, 1982). When the raw linguistic interface - the vocabulary item or the pronunciation of itblocked entry to meaning-making, the larger text could not be accessed, much less processed. My processing of Alberto's Spanish was top-down, driving real communication. But with Maria Elena's rapid conversations, my listening was short-circuited and I was jolted back to bottom-up decoding, trying to identify individual words being said. It was frustrating and confidence-deflating.

According to Gass and Selinker (2001), focus on form requires "meaningfocused activity into which an attention to form is embedded" (p. 320). This was elusive in my coursework: Linda's unrelenting grammar study was tiring; Juanita's admonitions to memorize decontextualized irregular verb forms that were not systematically woven into more communicative moments were functionally pointless; Margarita's isolated grammar lessons were rapid, unintegrated afterthoughts tacked onto the tail end of classes such that I could not place needed forms in a meaningful context. The present subjunctive swam around in my brain, emerging occasionally in the eavesdropped conversations of others. I felt a pressing need for the integration of grammatical forms with real-life conversations, a move toward a more practical communicative competence in contrast to the structural approach followed in class.

Output provided a notable learning incentive in several language experiences, none of which occurred in class time, in keeping with Swain's (1985) observation underpinning her comprehensible output hypothesis: "Immersion students, then, have-relative to 'street learners' of the target language-little opportunity to engage in two-way, negotiated meaning exchanges in the classroom" (p. 247). According to Swain's $(1985,1993,2005)$ theory, comprehensible output is a necessary mechanism for language acquisition that provides opportunities to move language from a semantic domain to a syntactic realization. Needing to purchase medicine for Maya honed my every communicative resource: the consequences were dire. In needing to find the right words in other social circumstances such as cucharas for the ice cream spoons and lentes for glasses, social reception was an important factor: when I was with fellow learners, goofs were funny; in other social circumstances they were highly embarrassing. This made for potent memory storage and highly effective learning! 


\section{On the Teacher}

My repositioning from professor of multilingual education and former English (as a second) language teacher to classroom learner permitted me to read the teacher's professional investment in our class sessions: her planning; management of class interaction; and sensitivity to individual factors such as interest, motivation, goals, and aptitude. Linda, Juanita, and Margarita were all capable teachers in their own ways; I did not suffer from poor or unprepared teachers in my formal language study, although their approaches were constrained by the materials and the nature of week-by-week teaching to small groups at variable proficiency levels. My teachers had varying levels of teaching experience and varied understandings of how I was to learn Spanish, ranging from the highly practical—commiserating conversations with Margarita about our personal lives as middle-aged mothers-to the ridiculous-being advised by Linda to use Spanish all the time with everyone. The teachers used the same materials in quite disparate ways, Linda sticking to the letter of each page, and Margarita paying little attention to the book's grammatical progression, preferring conversation.

\section{On Being a Language Learner}

I suppose that if one had to identify one of the most telling factors in the relatively short-lived if intense history of studies in second-language acquisition, it would have to be the consistent anonymising, if not the actual eclipsing, of the learner. (Candlin, cited in Norton, 2000, p. xiii)

My Spanish language proficiencies have indeed improved considerably, as has my confidence in navigating a Hispanic cultural milieu. Both Maya and I learned quickly, having had prior exposure to other languages in which we had variable proficiencies, although our classroom experiences were vastly different. Where I missed the friendly competitive edge of my classmate when he left for home after two weeks together, Maya on the other hand was liberated when her classmate, who dragged the level of her beginners' class down to the lowest levels, dropped out.

Aronin and Ó Laoire (2004) sweepingly suggest that "multilinguals are qualitatively different from monolinguals and even bilinguals" (p. 25). However, defining multilingual competence invokes argument: multilingualism is unfairly envisaged as multiple monolingual competences rather than as a functional distribution of multiple language proficiencies (Cenoz \& Genesee, 1998). As Bialystok (2001) points out, "for adults, the idea of an 'uncontaminated' monolingual is probably a fiction" (p. 1). Nonetheless, no matter how multilingualism is defined, research on cognitive and affective factors implicated in successful individual second-language learning (Ellis, 1994; Naiman et al., 1996; Skehan, 1989) does not explain the broad social 
phenomenon of the bilingual/multilingual excelling at the acquisition of subsequent languages.

Still, I felt vulnerable as a language learner: frustratingly locked inside an English-speaking self and communicating on a basic level in a language that I had to search for in my brain and mouth, inarticulate, no longer protected by my professionalism. Without my language abilities I was indeed another person-one on whom the general population looked kindly if somewhat condescendingly as a tourist of little consequence-and I was conscious of my anxiety levels in social interactions despite my apparent "willingness to communicate" in Spanish (Baker \& MacIntyre, 2003; Dörnyei, 2003).

As Pavlenko (2002) states, "not all languages, discourses or registers are equal in the linguistic marketplace: some are "more equal than others"' (p. 283). This language-learning adventure was an enrichment opportunity for my daughter and myself. Our lives will not come to an abrupt economic end without sufficient, effective Spanish, nor will we be denied an appropriate place in society or access to further education, nor be propelled into a frustrating chase after enough language to understand conceptual matters in life and learning. These are not consequences for optional second-language learners.

I now ask myself how adult immigrants feel, stripped of their professional history, social dignity, and communicative apparatus for economic and social survival. My experience as an adult language learner in Costa Rica has deeply sharpened my comprehension of and my compassion for language learners' struggle for basic human expression:

So too does our language touch the language of the other. Yet it also holds us within ourselves, holds our selves within us. We might think about a second language as a kind of second skin, enveloping the first, separating us by a layer from what is other to us, but incorporating at the same time a second set of nerve endings, twice as much feeling, intensifying the longing for connection with that other. (Granger, 2004, p. 108)

\section{The Author}

Heather Lotherington is an associate professor of multilingual education at York University and past Co-Editor of the Canadian Modern Language Review. Her research foci include multiliteracies, multilingual acquistion and education, and digital literacies. She is currently directing a collaborative study on emergent multiliteracies in the elementary school focusing on children's construction of postmodern, digital, multilingual narratives.

\section{References}

Aronin, L., \& Ó Laoire, M. (2004). Exploring multilingualism in cultural contexts: Towards a notion of multilinguality. In C. Hoffman \& J. Ytsma (Eds.), Trilingualism in family, school and community (pp. 11 - 29) Clevedon, UK: Multilingual Matters.

Baker, S., \& MacIntyre, P. (2003). The role of gender and immersion in communication and second langauge orientations. In Z. Dörnyei (Ed.), Attitudes, orientations, and motivations 
in language learning: Advances in theory, research, and applications. Language Learning, 53 (Supplement 1), 65-96.

Bialystok, E. (2001). Bilingualism in development: Language, literacy and cognition. Cambridge, UK: Cambridge University Press.

Block, D., \& Cameron, D. (2002). Introduction. In D. Block \& D. Cameron (Eds.), Globalization and language teaching (pp. 1-10). London: Routledge.

Castells, M. (2000). The rise of the network society. Volume 1: The information age: economy, society and culture (2nd ed.). Oxford, UK: Blackwell.

Cenoz, J., \& Genessee, F. (1998). Psycholinguistic perspectives on multilingualism and multilingual education. In J. Ceñoz \& F. Genessee (Eds.), Beyond bilingualism: Multilingualism and multilingual education (pp. 16-32). Clevedon, UK: Multilingual Matters.

Clyne, M. (1994). Inter-cultural communication at work: Cultural values in discourse. Cambridge, UK: Cambridge University Press.

Crystal, D. (2001). Language and the Internet. Cambridge, UK; New York: Cambridge University Press.

Dörnyei, Z. (Ed.). (2003). Attitudes, orientations, and motivations in language learning: Advances in theory, research, and applications. Language Learning, 53(Supplement 1), 3-32.

Doughty, C.J. (2004). Effects of instruction on learning a second language: A critique of instructed SLA research. In B. VanPatten, J. Williams, S. Rott, \& M. Overstreet (Eds.), Form-meaning connections in second language acquisition (pp. 181-202). Mahwah, NJ: Erlbaum.

Ellis, C., \& Bochner, A.P. (Eds.). (1996). Composing ethnography: Alternative forms of qualitative writing. Walnut Creek, CA; Altamira.

Ellis, R. (1994). The study of second language acquisition. Oxford, UK: Oxford University Press.

Gass, S., \& Selinker, L. (2001). Second language acquisition: An introductory course (2nd ed.). Mahwah, NJ: Erlbaum

Granger, C. (2004). Silence in second language learning. Clevedon, UK: Multilingual Matters.

Harris, R., Leung, C., \& Rampton, B. (2002). Globalization, diaspora and language education in England. In D. Block \& D. Cameron (Eds.), Globalization and language teaching (pp. 29-46). London: Routledge.

Heller, M. (2002). Globalization and the commodification of bilingualism in Canada. In D. Block \& D. Cameron (Eds.) Globalization and language teaching (pp. 47-63). London: Routledge.

Holt, N.L. (2003). Representation, legitimation, and autoethnography: An autoethnographic writing story. International Journal of Qualitative Methods, 2(1), 1-22.

Hudson, T. (1982). The effects of induced schemata on the "short circuit" in L2 reading: Non-decoding factors in L2 reading performance. Language Learning, 32(1), 1-31.

Kendris, C. (1996). 501 Spanish verbs (4th ed.). Hauppauge, NY: Barron's Educational.

Kinginger, C. (2004). Alice doesn't live here anymore: Foreign language learning and identity reconstruction. In A. Pavlenko \& A. Blackledge (Eds.), Negotiation of identities in multilingual contexts (pp. 219-242). Clevedon, UK: Multilingual Matters.

Krashen, S. (1981). Second language acquisition and second language learning. Oxford, UK: Pergamon.

Krashen, S. (1982). Principles and practice in second language acquisition. Oxford, UK: Pergamon.

Krashen, S. (1985). The input hypothesis: Issues and implications. London: Longman.

Johnson, R.K., \& Swain, M. (Eds.). (1997). Immersion education: International perspectives. Cambridge, UK: Cambridge University Press.

Lambert, W. (1974). Culture and language as factors in learning and education. In F. Aboud \& R. Meade (Eds.), Cultural factors in learning and education. 5th Western Washington symposium on learning (pp. 91-122), Bellingham, WA.

Lambert, W.E., \& Tucker, G.R. (1972). Bilingual education of children: The St. Lambert experiment. Rowley, MA: Newbury House. 
Lotherington, H. (2004a). What four skills? Redefining language and literacy skills in the digital era. TESL Canada Journal, 22(1), 64-78.

Lotherington, H. (2004b). Bilingual education. In A. Davies \& C. Elder (Eds.), The handbook of applied linguistics (pp. 695-718). Oxford, UK: Blackwell.

Lotherington, H. (2006). Multiliteracies at Main Street School: Digital texts, multilingual development and inclusive narratives. Contact, 32(2), 72-85.

Mitchell, R., \& Myles, F. (1998). Second language learning theories. London: Arnold.

Naiman, N., Frölich, M., Stern, H.H., \& Todesco, A. (1996). The good language learner. Clevedon, UK: Multilingual Matters.

Norton, B. (2000). Identity and language learning: Gender, ethnicity and educational change. Harlow, UK: Pearson Education.

Pavlenko, A. (2002). Poststructuralist approaches to the study of social factors in second language learning and use. In V. Cook (Ed.), Portraits of the L2 user (pp. 277-302). Clevedon, UK: Multilingual Matters.

Reed-Danahay, D. (1997). Auto/ethnography: Rewriting the self and the social. New York: Berg.

Skehan, P. (1989). Individual differences in foreign language learning. London: Edward Arnold.

Swain, M. (1985). Communicative competence: Some roles of comprehensible input and comprehensible output in its development. In S.M. Gass \& C.G. Madden (Eds.), Input in second language acquisition (pp. 235-253). Rowley, MA: Newbury House.

Swain, M. (1993). The output hypothesis: Just speaking and writing aren't enough. Canadian Modern Language Review, 50(1), 158-164.

Swain, M. (2005). The output hypothesis: Theory and research. In E. Hinkel (Ed.), Handbook of research in second language teaching and learning (pp. 471-484). Mahwah, NJ: Erlbaum. 